\title{
Urban Wastewater Treatment in African Countries: Evidence from the Hydroaid Initiative
}

\author{
Marco Ravina ${ }^{1, *}\left(\mathbb{D}\right.$, Sergio Galletta ${ }^{2}$, Augustin Dagbetin ${ }^{3}{ }^{-}$, Omama Ahmed Hussein Kamaleldin ${ }^{4}$, \\ Madalitso Mng'ombe ${ }^{5} \mathbb{D}^{(}$, Lameck Mnyenyembe ${ }^{6}$, Alemayehu Shanko ${ }^{7}$ (D) and MariaChiara Zanetti ${ }^{1}$ \\ 1 Department of Environment, Land and Infrastructure Engineering (DIATI), Politecnico di Torino, \\ 10129 Torino, Italy; mariachiara.zanetti@polito.it \\ 2 Hydroaid-Water for Development Management Institute, 10122 Torino, Italy; sergio.galletta@hydroaid.it \\ 3 Laboratory of Applied Hydrology (LHA), National Institute of Water (INE), \\ University of Abomey-Calavi (UAC), Cotonou 01 BP 526, Benin; augustin.dagbetin@gmail.com \\ 4 Water Engineering and Environment Department, Faculty of Engineering, Cairo University, \\ Giza 12613, Egypt; Omama.ahmed@yahoo.com \\ 5 Department of Water and Sanitation, Mzuzu University, Mzuzu 105200, Malawi; \\ madalitsomngombe@gmail.com \\ 6 Catholic Development Commission in Malawi (CADECOM), Mzuzu 105200, Malawi; \\ mnyenyembelamey@gmail.com \\ 7 HU.Department of Irrigation and Water Resources Engineering, Hawassa University, \\ Hawassa 387-0006, Ethiopia; alemayehudula@gmail.com \\ * Correspondence: marco.ravina@polito.it
}

check for updates

Citation: Ravina, M.; Galletta, S.; Dagbetin, A.; Kamaleldin, O.A.H.; Mng'ombe, M.; Mnyenyembe, L.; Shanko, A.; Zanetti, M. Urban Wastewater Treatment in African Countries: Evidence from the Hydroaid Initiative. Sustainability 2021, 13, 12828. https://doi.org/ $10.3390 /$ su132212828

Academic Editor: Athanasia Tolkou

Received: 4 November 2021

Accepted: 16 November 2021

Published: 19 November 2021

Publisher's Note: MDPI stays neutral with regard to jurisdictional claims in published maps and institutional affiliations.

Copyright: (C) 2021 by the authors. Licensee MDPI, Basel, Switzerland. This article is an open access article distributed under the terms and conditions of the Creative Commons Attribution (CC BY) license (https:/ / creativecommons.org/licenses/by/ $4.0 /)$.

\begin{abstract}
This study is based on the evidence collected during the "Technical e-Learning Course on Wastewater Treatment", an international training project developed in 2020 in Italy by the Hydroaid Association, in collaboration with Turin Polytechnic. This work intended to address the sustainability of urban sanitation in various African countries, which the world of international cooperation has been looking at in recent years with growing interest. A comparative analysis of the current strategies and technological solutions was conducted. Data and information reported by the project participants were elaborated and verified. Four African countries-Benin, Egypt, Ethiopia, and Malawi-were considered and two relevant case studies among those proposed by the participants were presented. Starting from this analysis, significant elements about the status and coverage of wastewater management were extracted and reported. The analysis of existing wastewater treatment plants (WWTPs) allowed evaluating their design features and current status of operation. Considerations about the environmental, economic, social, and technical sustainability of wastewater treatment and management were finally reported. Conducting such an analysis provided support in identifying the best practices and the most recurrent problems linked to the various African contexts, which need to be considered for a complete definition of the planning strategy for accessible, efficient, and sustainable sanitation infrastructures.
\end{abstract}

Keywords: wastewater treatment; Africa; sanitation; Sustainable Development Goals

\section{Introduction}

Global water demand will increase significantly in the next few decades. Agriculture is responsible for $70 \%$ of total freshwater consumption worldwide $(90 \%$ in the least developed countries), while energy and industry are responsible for $20 \%$. The remaining $10 \%$ is used for drinking water, sanitation, hygiene, and other domestic purposes [1]. The causes for this increase are mainly population growth, the rapid urbanization to which is added the development of water supply and sanitation systems, and the improvement of lifestyles [2].

Four billion people (almost two-thirds of the world's population) currently live in areas affected by water scarcity for at least one month each year. Lack of non-renewable resources, such as fossil groundwater, will force to transfer water from areas rich in water 
or to displace people in case of severe water scarcity. Climate change will aggravate the scarcity of water issues because the variations of the water cycle increase the gap between water demand and water supply, exacerbating the extreme events at the local level (floods and droughts) [1]. The availability of water resources is strictly linked to water quality, because the increase of agricultural runoff and untreated wastewater from industry or domestic use lead to the degradation of the environment and the water sources, deteriorating the water quality in the world. If this trend remains unchanged over the next few decades, especially in countries in arid areas, water quality degradation will further contribute to water scarcity, endangering human health and ecosystems, and holding back sustainable development.

Therefore, wastewater is a crucial component of water resource management. Neglecting wastewater issues generates significant negative impacts on the environment, the occurrence of waterborne diseases due to the use of contaminated water sources, and the well-being of communities [3]. Underestimating the impacts related to wastewater means seriously compromising the achievement of the Sustainable Development Goals (SDGs) of the 2030 Agenda. In particular, the SDG Target 6.3 states: "By 2030, improve water quality by reducing pollution, eliminating dumping, and minimizing release of hazardous chemicals and materials, halving the proportion of untreated wastewater and substantially increasing recycling and safe reuse globally." The achievement of this target is critical for achieving the entire 2030 Agenda and, in particular, for SDGs concerning health, education, cities, and industry.

Freshwater withdrawn for human activity stands at nearly $4000 \mathrm{~km}^{3} /$ year across the globe. $56 \%$ of it is discharged as wastewater from urban and industrial activities or drainage from irrigation water. High-income countries collect and treat the majority of wastewater worldwide. In these countries, around $70 \%$ of urban and industrial wastewater is treated. Upper-middle-income countries treat only 38\%, for lower-middle-income countries the ratio is $28 \%$, while, in low-income countries, only $8 \%$ is treated. In developing countries, the release of untreated wastewater remains a common practice due to lacking infrastructure, technical and institutional capacity, and financing. Wastewater management services are generally inadequate, thus wastewater treatment and disposal is a matter of concern that needs to be addressed [4].

Considering the figures related to Africa, the situation is critical. Africa is the second driest continent after Oceania and less than $9 \%$ of the global renewable water resources $\left(3930 \mathrm{~km}^{3}\right)$ are located there. Moreover, there is also a huge disparity across African countries, ranging from $25 \mathrm{~m}^{3}$ /inhabitant/year of renewable water in Egypt to $121,000 \mathrm{~m}^{3}$ /inhabitant/year in Gabon. Only a few of the 54 African countries-and almost all located in the northern region-met the Millenium Development Goal (MDG) target for sanitation. Nearly 750 million people (69\% of the African population) - mostly in sub-Saharan countries — did not have access to improved sanitation services in 2017 [5].

This research study intends to address the sustainability of urban sanitation in various African countries, which the world of international cooperation has been looking at in recent years with growing interest. The objective is reached through a comparative analysis of the current strategies and technological solutions which, in the vast sphere of sanitation, refer to the management and treatment of urban wastewater in African countries. Conducting such an analysis in different countries provides support in identifying the best practices and the most recurrent problems linked to the various African contexts, which need to be considered for a complete definition of the planning strategy for accessible, efficient, and sustainable sanitation infrastructures from an economic, social, and environmental point of view.

To overcome the objective, the shreds of evidence from the 2020 edition of the Hydroaid "Technical e-Learning Course on Wastewater Treatment" were considered. Hydroaid is a non-profit association founded in 1999 in Turin, Italy, with the mission to contribute to the strengthening of knowledge, skills, and competencies for the sustainable management of water resources in developing and emerging countries. The Hydroaid training project was open to local experts in the wastewater management sector and intended 
to contribute to the improvement of the area of sanitation that is wastewater management, by promoting an approach based on "learning from the roots", through the knowledge and analysis of the social context, and the comparison of the various experiences in the different realities of many African countries. As already reported by previous studies [6], achieving complete and accurate data on sanitation management in African countries is difficult. The possibility of obtaining data directly from local experts in the sector was considered an important advantage. This approach allowed the acquisition of detailed and specific information, otherwise hardly available.

This study is organized as follows. Data and information reported by the project participants are elaborated and verified. Starting from this analysis, significant elements about the status and coverage of wastewater (WW) management are extracted and reported in Section 3. Subsequently, the analysis is focused on existing wastewater treatment plants (WWTPs), evaluating their design and current status of operation (Section 4). Finally, considerations about the environmental, economic, social, and technical sustainability of WW treatment and management are reported (Section 5).

\section{Methodology}

Since 2001, the Hydroaid association (Hydroaid) has promoted and implemented training and capacity development activities on issues related to water resource management for the benefit of 89 countries, building an international network of about 5000 experts composed of technicians, managers, decision-makers, trainers, and students. In 2011, Hydroaid was granted the special consultative status with the United Nations Economic and Social Council (UN ECOSOC). Training courses implemented by Hydroaid concern multiple aspects of water resources: design and management of water supply and sanitation systems, governance, planning, economic regulation, and climate change. These training activities can be integrated in broader capacity development initiatives aimed at supporting and reinforcing the institutional and technical local partners in international cooperation projects in developing and emerging countries, in collaboration with its members, NGOs, and partners. Since its establishment, the Hydroaid Association has Politecnico di Torino as one of its main supporting members. The membership of Politecnico di Torino has made it possible to implement didactic and scientific skills into the association activity.

This research work is based on the shreds of evidence of the Hydroaid "Technical e-Learning Course on Wastewater Treatment", edition 2020, delivered in May 2020 for a 5-month duration and in collaboration with Politecnico di Torino. The course was held online. It provided the key elements for the design, management, and maintenance of wastewater treatment plants and the reuse of water for industrial, agricultural, and domestic purposes. Feasible and most effective technologies, i.e., from the most advanced treatments to those technically simpler, were presented and discussed. The course was open to 102 participants from 33 countries. 71 participants came from 20 African countries. The African countries with the highest number of participants were: Ethiopia (11), Tanzania (10), Malawi (8), Kenya (5), Rwanda (4), Egypt (3), and Zambia (3).

\subsection{Research Design}

The main research method used in this study was qualitative research. Qualitative data and information for the research process were collected from the outcome of the course assignments, thematic forums, and interviews. The methods mentioned above were used to outline the scientific issue and identify determinants [7]. Similar methods were adopted by other scholars in the study of sustainable development of low-income countries, due to their applicability in case of data scarcity [8]. In addition, desk-based research was carried out by a review of available sources published so far. Text mining methods and techniques, as well as text analysis, were also applied in this research to extract facts and to verify and integrate the available data. A secondary source that was used to integrate basic data and information came from international institution documents, like the United Nations (UN) and the World Bank. 
A significant amount of data was collected by the contribution of all the 71 participants. Such data were analysed and elaborated to collect information about the status, regulation, and coverage of WW management in the country they belong to, as well as collecting information on WWTPs currently in operation. Given the high amount of data, the analysis was restricted to four African countries and two case studies. The selection of representative countries was based on geography and data completeness. Different African regions (North, West, East, Central, and South Africa) were considered to take into account different contexts around the continent. The four African countries selected were Egypt, Benin, Ethiopia, and Malawi (Figure 1).

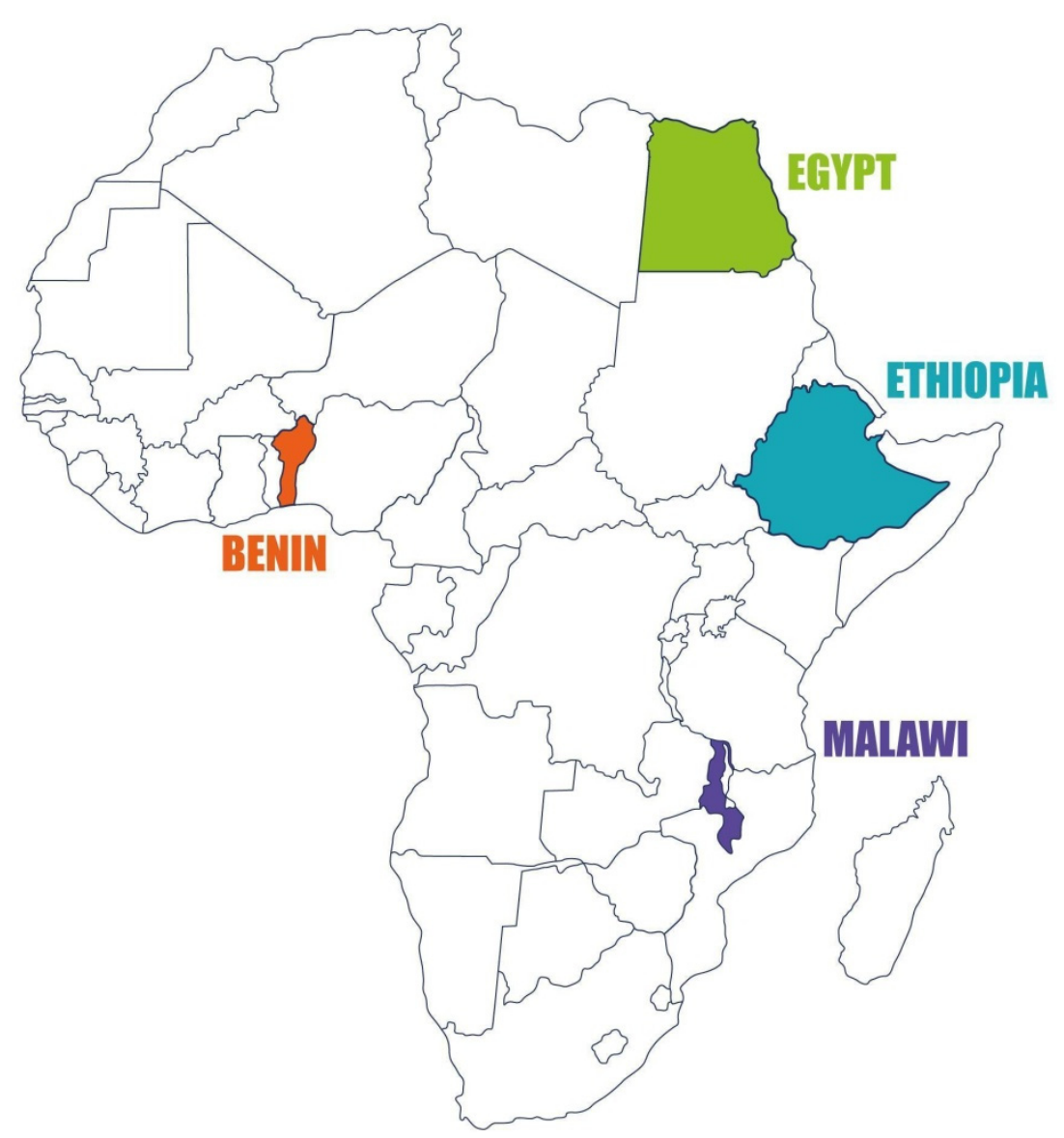

Figure 1. African countries selected for the study.

The information collected was verified and integrated with the aid of the participants who showed the highest competence, motivation, and interaction during the training course. Among the case studies presented by the participants, the most complete and interesting in terms of data and information available are presented. The two WWTPs selected were the Kaliti plant in Addis Ababa, Ethiopia, and the Kauma plant in Lilongwe, Malawi.

\subsection{Description of Hydroaid Training Project}

The interaction between the participants and the teacher/tutor and between the participants themselves was possible thanks to the provision of thematic forums or discussions on the platform. The participants were asked to describe the wastewater governance in their own country and in particular: (i) to mention the main reference documents, such as principles, policy, and strategies, (ii) to point out the main stakeholders, such as regulatory body, service providers, local and national authorities involved, including their roles and responsibilities, and (iii) to provide an overview of the wastewater system management, 
introducing the situation about sewer and treatment plants, weaknesses and challenges to be faced.

At the end of the course, participants were asked to describe a specific wastewater plant operating in their own country, including technical data of the plant, main evidence about environmental impacts, financial data, and social impacts on the community. The environmental impacts caused by the plant had to be analyzed mainly concerning (i) final quality of the treated wastewater that is discharged into water bodies; (ii) possible residual pollutants and/or pathogens contained in the reused wastewater (if wastewater is reused); (iii) possible residual pollutants and/or pathogens in the treated wastewater sludge; (iv) possible emissions into the atmosphere of hazardous pollutants, odours or greenhouse gases deriving from the process [9]. The financial data of the plant concerned the payment or not of taxes or fees by citizens or companies for the sanitation service, the identification of the main stakeholders involved, the economic sustainability of the plant, the description of economic revenues or savings due to the recovery of energy (e.g., biogas) and material (e.g., reused water or sludge). The social impacts on the local community meant to identify aspects, related to religion or habits, in conflict with the operation and aims of the plant, and the impacts of the plant on the local population in terms of advantages for the access to sanitation service, generation, and remuneration of jobs.

\section{Status and Coverage of WW Management}

In the present section, a resume on the status, coverage, and challenges of wastewater treatment (WWT) in the selected African countries is reported.

\subsection{Egypt}

In Egypt, the total length of sewage networks amounts to around 45,000 km. Around $60 \%$ of the total population is served by sewage systems, mostly in big urban areas. Of the rest, 35\% have indirect access to sanitation, and nearly 5\% have no access. Non-served people may have a private system with help from community organizations, usually a septic tank. Policies related to the Egyptian water sector are set by several ministries. The Ministry of Water Supply and Sewerage Facilities, established in 2012, assumed the functions of the Ministry of Housing and Urban Communities, which was previously responsible for this sector. The Ministry of Water Resources and Irrigation is responsible for the management of water resources and irrigation and supervises all institutions responsible for providing water and sanitation services. The Ministry of Health and Population is responsible for analysing the water quality. The Holding Company for Drinking Water and Wastewater, which was established in 2004, is responsible for the financial and technical sustainability of the existing governorate. The Egyptian Water Regulatory Agency, which was established in 2006, is responsible for economic and technical regulation in public utilities. The three institutions that are responsible for planning and overseeing infrastructure construction are the Cairo and Alexandria Potable Water Organization (CAPWO) for the country's two largest cities, and the National Organization for Drinking Water and Sanitation (NOPWASD) is for the rest of the country except for the new urban communities. The New Urban Communities Authority is responsible for water supply and sanitation investments in new societies, through which 29 drinking water stations have been built that serve 5 million residents of those communities, 10,000 km of water pipelines, and $7000 \mathrm{~km}$ of pipelines sewerage, and 26 wastewater treatment plants. The Holding Company for Water and Waste Water (HCWW) and its 26 subsidiary companies are responsible for the operation and maintenance of water and wastewater. In Egypt, the main reference that controls the wastewater management process is the Egyptian Code for Sanitary Drainage Networks [10]. Concerning water management, water balance in Egypt will probably be affected by the construction of the Grand Ethiopian Renaissance Dam (GERD). This project is generating conflicts, as Egypt jointly with Sudan recently took the GERD dispute file to the United Nations Security Council [11]. 


\subsection{Benin}

According to a survey conducted in Benin in 2018 by the National Institute of Statistic and Economic Analysis (INSAE), only $12.8 \%$ of Benin citizens have access to a suitable sewage system. The majority of the population uses self-built sewage systems, or have access to community latrines. Wastewater is largely disposed of in courtyards or streets. In Benin, sanitation is relatively young and became prominent in 2003. The central government saw the need to decentralize sanitation to the municipality level. Results from this strategy saw the development of sanitation and sewerage facilities in the big towns. In the rural areas, the use of toilets and the practice of basic hygiene at home and schools were encouraged. The Benin Republic has its legal framework regarding wastewater management. This is contained in the following reference strategic documents: National Strategy for Wastewater Sanitation in Urban Areas (2008-2015) [12], National Health Development Plan (2009-2018) [13], Benin Blue Book [14], National Water Policy [15] and Decree 2001-109 of 4 April 2001, fixing the quality standards of residual water in the republic of Benin [16].

Regarding the main actors in wastewater management, the Ministry of Mines, Energy, and Water develops and coordinates the implementation of the government's policy in the water sector. The Health Ministry develops and coordinates the implementation of the government's policy in the hygiene and basic sanitation sector. The National Directorate of Public Health (DNSP), attached to the Ministry of Health promotes hygiene and basic sanitation in rural areas, relayed locally by the SHABs (Departmental Hygiene and Basic Sanitation Services). The National Water Society of Benin (SONEB) is in charge of drinking water supply, sewage disposal, and treatment in urban areas. Municipalities are the owners of water and sanitation utilities and those responsible for planning, financing, building, and operating drinking water supply, and sanitation infrastructures in rural and urban areas. Finally, local and collective non-profit organizations (NGOs) elaborate and coordinate projects, ensure their management as a support operator for municipal project management, often in partnership with decentralized and non-governmental cooperation actors.

\subsection{Ethiopia}

According to $2021 \mathrm{WHO}$ /UNICEF Joint Monitoring Program for Water report [17], $73 \%$ of Ethiopia's urban and $77 \%$ of its rural population used unimproved sanitation facilities, with $8 \%$ in urban and $43 \%$ in rural communities practicing open defecation. In general, sanitation systems are present in larger urban areas like Addis Ababa (capital city), and State/Regional capital cities. In the rest of the country, community sanitation is poor. In recent decades, urban sanitation interventions have focused on increasing access to improved toilet facilities, with little attention paid to ensuring that wastewater is adequately collected and treated before discharge into the environment. Despite the availability of Health Extension Workers (HEW) in all Ethiopian towns, more than $60 \%$ of households in urban areas use traditional pit latrines and about $6 \%$ of urban residents are still practicing open defecation. Faecal sludge is often accumulated in poorly designed and built pits, and then discharged directly into storm drains, open water bodies, seep into the ground, or is manually removed from the pit and dumped into the environment. Addis Ababa is the only urban center with a sewer connection in Ethiopia, that serves about 10\% of the population.

In Ethiopia, the Ministry of Water Irrigation and Electricity (MoWIE), Ministry of Urban Development and Construction (MoUDC), and Ministry of Health (MOH) share responsibilities for monitoring and overseeing the hygiene and sanitation services at the national level. Water and Sewerage Authorities in each municipality are legally mandated to provide sanitation services in large cities. In most cities, municipalities are responsible for managing wastewater management. The regional Water Bureau mainly supervises the construction of water supply utilities. They also supervise the activities of water supply and sanitation projects undertaken by private agencies, like NGOs. The constructed facilities will be then handled by the town administration. Town water utilities are accountable to Water Boards. The Water Boards act on behalf of the town administration (Ethiopian 
Ministry of Water Resources, Irrigation, and Electricity [18]). While Utilities are directly accountable to an autonomous Water Board, which is in turn partly regulated by the Regional Water Bureaus. The MoUDC, in its effort to exercise its mandate of monitoring standards of municipal services, also plays a part in monitoring the performance of utilities.

The main regulatory policies include the Environmental Pollution Control Proclamation $n^{\circ} 300 / 2002$, developed by Ministry of Environment, Forest and Climate Change (formerly EPA); the Ethiopian Public Health Proclamation $n^{\circ} 200 / 2000$, developed by Ministry of health; the Proclamation $n^{\circ}$ 661/2009 developed by the Food, Medicine and Health Care Administration and Control Authority; and the National Strategy for Improved Hygiene and Sanitation (Ethiopian Ministry of Water Resources, Irrigation and Electricity [19]).

Concerning water management, the Grand Ethiopian Renaissance Dam (GERD) project, whose construction started in 2011, will probably boost the water and energy availability of the country. However, according to Morsy et al. [11], an environmental impact assessment of the GERD project is presently absent. The same authors also highlight that infrastructure of such magnitude will cause significant social and environmental impacts, like involuntary displacement, general detriment of water quality, and loss of biodiversity.

\subsection{Malawi}

Malawi is one of the most densely populated countries in Africa, with a population density of 129 persons $/ \mathrm{km}^{2}$ [20]. As reported by Msilimba and Wanda [21], about 15\% of the population is connected to waterborne sewerage and $15 \%$ to septic tanks. It is estimated that only $5.4 \%$ use flush toilets (to sewer and septic tanks), 1.4\% use Eco-san toilets, and the remaining $93.2 \%$ rely on pit latrines [22]. The main centralized treatment plants are located in the cities of Blantyre, Zomba, Lilongwe, and Mzuzu. For instance, wastewater flow diagrams reported in Figures 2 and 3 for Blantyre City and Kasungu municipalities reveal that $34 \%$ and $66 \%$ of liquid waste generated in Blantyre and Kasungu respectively is safely managed. For offsite sanitation, only $1 \%$ out of $10 \%$ wastewater contained is treated, $8 \%$ of wastewater is not delivered to treatment, the remaining $1 \%$ is not treated for Blantyre city. In Kasungu, in terms of offsite sanitation, only $1 \%$ out of $5 \%$ wastewater contained is treated. The proportion of wastewater not delivered to treatment is $3 \%$ while the remaining $1 \%$ is not treated $[23,24]$.

The majority of inhabitants in the municipality just discharge the untreated wastewater in the storm drains and natural waterways. A minor part discharges the wastewater in their household septic tanks which discharge into the soils or is collected by the city councils. Mostly, when the latrine is full, they abandon it and dig another. Effluents from septic tanks are collected and discharged into sewerage systems by either city councils or private operators who operate emptying business. Mr. Clean Malawi is a good example of the business of emptying the septic tanks and pit latrines in Mzuzu City.

In Malawi, wastewater generation has increased due to an increase in population, urbanization, and industrialization [21]. Key policies and legislation guiding management and operations of wastewater in Malawi include Guidelines for the Design, Operations and Maintenance of Waste Stabilization Ponds in Malawi (2012), Waterworks Act (1995) [25], Water Resources Act (2013) [26], National Sanitation Policy (2006) [27], Local Government Act (1998) [28], Public Health Act (1948), and quality standards guided nationally by the Malawi Bureau of Standards (MBS MS539:2002 and MS691:2005) [29]. International and regional standards and guidelines such as World Health Organization (WHO) may also apply to complement the national standards. The legislation and policy mandate ministries and departments responsible for water affairs, sanitation, and public health to manage, monitor the development of water resources, utilization, and safe disposal of liquid waste among others to protect the environment. 


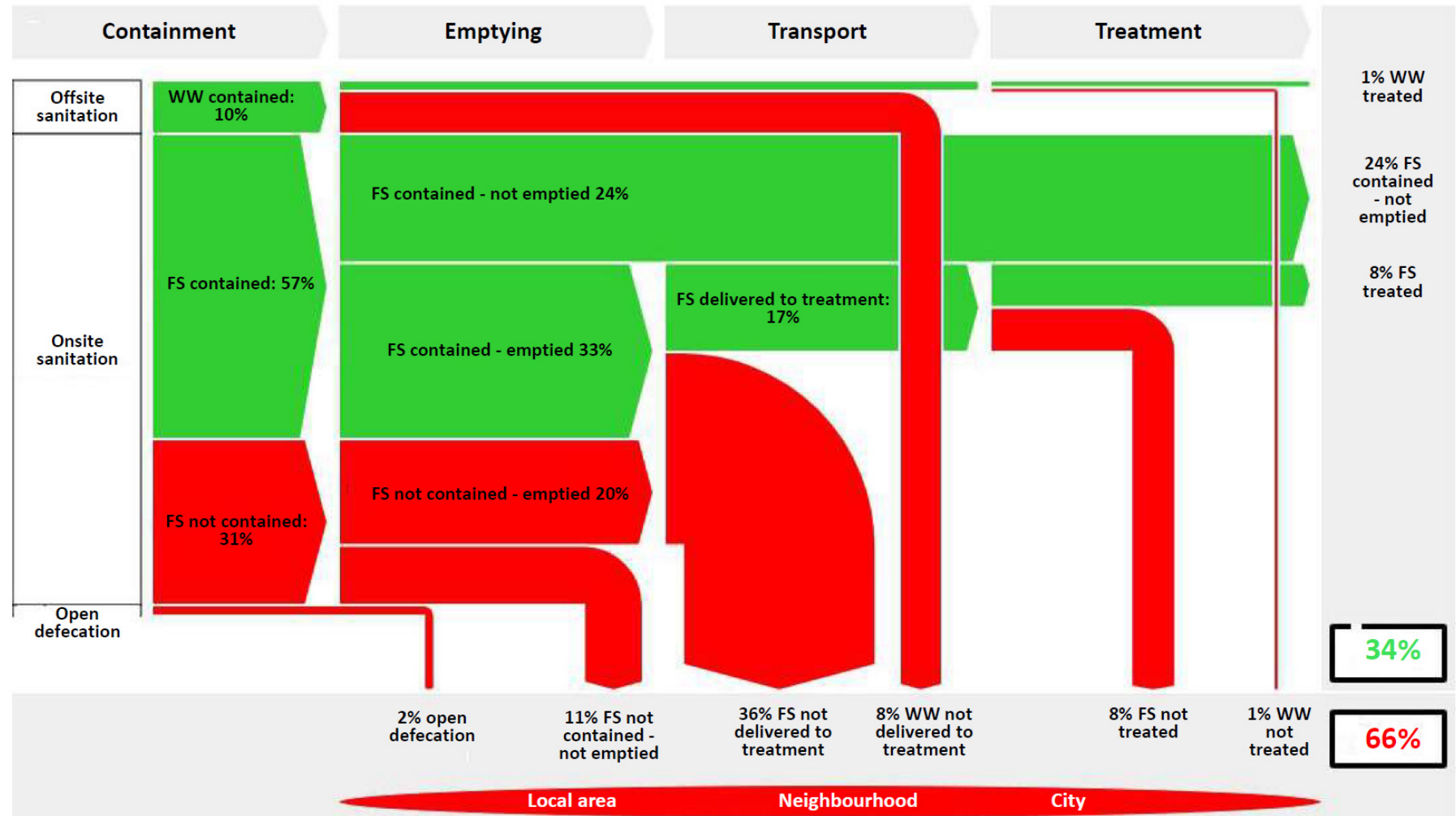

KEY: WW: wastewater, FS: faecal sludge, SN: supernatant

Safely managed

Unsafely managed

Figure 2. WW flow diagram of Blantyre city, Malawi [23].

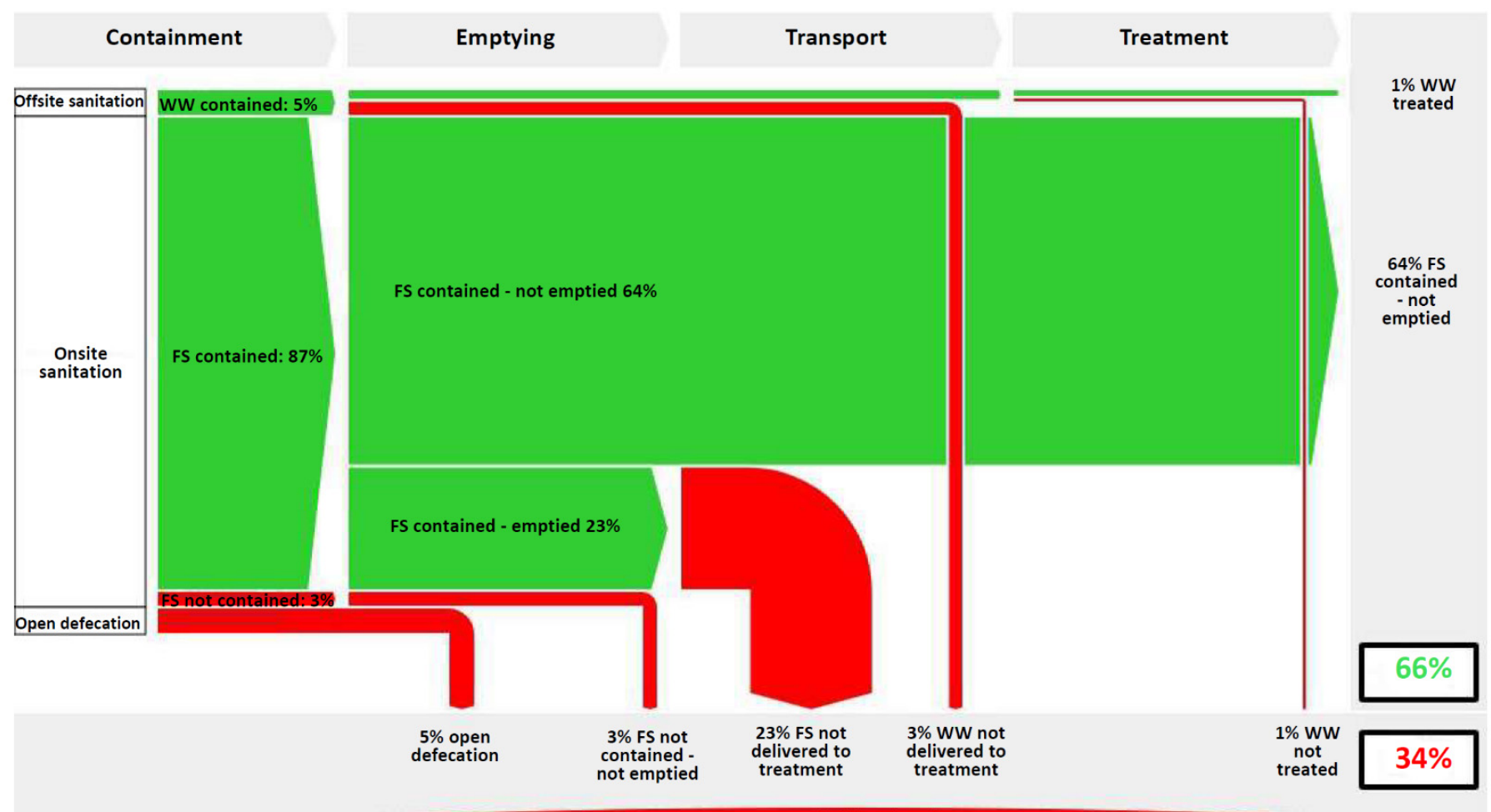

KEY: WW: wastewater, FS: faecal sludge, SN: supernatant

Safely managed

Unsafely managed

Figure 3. WW flow diagram of Kasungu city, Malawi [24]. 
In Malawi, the process of treating water and managing wastewater is done by the government with support from private entrepreneurs, Non-Governmental Organizations, and Donors. The National Water Resources Authority (NWRA) regulates and protects water resources quality from adverse impacts; issues water abstraction and effluent discharge rights; monitors and enforces conditions attached to permits for water use. District assemblies oversee the implementation of decentralization policies, including water resources management, and implement water and sanitation goals under decentralization reforms. City and regional water boards (i.e., Southern Region Water Board; Blantyre Water Board; Central Region Water Board; Northern Region Water Board) are responsible for water supply to regions and work with governments and community agencies to implement water and sanitation goals. Private entrepreneurs are mainly in the construction of latrines, septic tanks, pit emptying, and transportation of waste to the wastewater treatment Plants. NGOs and community-based organizations provide support to the construction of sanitation facilities, mainly in rural areas. Donors, mainly the World Bank and the European Investment Bank provide financial supports and loans to the government.

\section{Case Studies}

The case studies reported in this study are two centralized WWTPs serving highly populated urban areas. The first is the Kaliti WWTP, located in Addis Ababa, Ethiopia. The second is the Kauma WWTP, located in Lilongwe, Malawi. The technical configuration of the process of each case study is reported in Table 1. Single cases will be analysed in the following.

Table 1. Main features of the processes.

\begin{tabular}{|c|c|c|}
\hline Plant Name & Kaliti WWTP & Kauma WWTP \\
\hline Location & Addis Ababa, Ethiopia & Lilongwe, Malawi \\
\hline Altitude (m. above sea level) & 2200 & 1018 \\
\hline Geographical area & Flatland with hilly areas & Flatland \\
\hline Climate type & Humid subtropical & Subtropical \\
\hline Territorial constraints & $\begin{array}{l}\text { No territorial constraints } \\
\text { are present }\end{array}$ & $\begin{array}{l}\text { Environmentally protected } \\
\text { area; Landscape protected } \\
\text { area; Hydrogeological } \\
\text { risk area }\end{array}$ \\
\hline Equivalent inhabitants & $2,270,000$ & 55,000 \\
\hline $\begin{array}{l}\text { Average daily water demand } \\
\text { per inhabitant }(1 / \mathrm{hab} / \mathrm{d})\end{array}$ & n.d. & 40 \\
\hline $\begin{array}{l}\text { Average organic load only for } \\
\text { domestic wastewater } \\
\left(\mathrm{gBOD}_{5} / \mathrm{hab} / \mathrm{d}\right)\end{array}$ & 32 & 26 \\
\hline Wastewater typology & $\begin{array}{c}\text { Domestic; Chemical industry; } \\
\text { Textile industry; Meat and } \\
\text { sausage industry }\end{array}$ & Domestic \\
\hline $\begin{array}{c}\text { Type of wastewater treatment } \\
\text { plant }\end{array}$ & Anaerobic plant & Both \\
\hline Other input data & & $\begin{array}{c}\text { Physical and biological } \\
\text { treatments take place at the } \\
\text { WWTP through stabilization } \\
\text { ponds }\end{array}$ \\
\hline Preliminary treatments & Grit chamberlines and screens & $\begin{array}{l}\text { Screening; Grit tank; } \\
\text { Equalization tank }\end{array}$ \\
\hline
\end{tabular}


Table 1. Cont.

\begin{tabular}{|c|c|c|}
\hline Plant Name & Kaliti WWTP & Kauma WWTP \\
\hline Primary sedimentation & Circular & Rectangular \\
\hline Organic load treatment & Trickling filters & Maturation ponds \\
\hline Nutrient abatement & No treatment & No treatment \\
\hline Secondary sedimentation & Circular & $\begin{array}{c}\text { Rectangular (stabilization } \\
\text { ponds) }\end{array}$ \\
\hline Filtering & Constructed wetlands & No treatment \\
\hline Disinfection & No treatment & No treatment \\
\hline $\begin{array}{l}\text { Final destination of treated } \\
\text { wastewater }\end{array}$ & $\begin{array}{l}\text { Irrigation and agricultural } \\
\text { purposes }\end{array}$ & Discharge into Lilongwe River \\
\hline Sludge thickening & Gravity thickening & No treatment \\
\hline Sludge stabilisation & Anaerobic digestion & $\begin{array}{l}\text { Aerobic digestion. The aerobic } \\
\text { digestion takes place in the } \\
\text { Facultative oxidation ponds } \\
\text { for a maximum retention } \\
\text { period of } 21 \text { days after which } \\
\text { the wastewater is discharged } \\
\text { into the receptor body. }\end{array}$ \\
\hline Sludge hygienisation & No treatment & No treatment \\
\hline Sludge drying & $\begin{array}{c}\text { Sludge drying beds and } \\
\text { lagoons }\end{array}$ & $\begin{array}{c}\text { Sun dried. After } \\
\text { sedimentation has taken place } \\
\text { in both anaerobic and } \\
\text { facultative ponds sludge is } \\
\text { directed to drying } \\
\text { ponds/beds through gravity. }\end{array}$ \\
\hline Sludge Incineration & No treatment & No treatment \\
\hline
\end{tabular}

\subsection{Kaliti WWTP (Addis Ababa, Ethiopia)}

Addis Ababa is the capital and largest city in Ethiopia. It is located on a plateau in the center of the country, at an elevation of $2200 \mathrm{~m}$, and forms part of the watershed for the Awash River. The city is the seat of the government of Ethiopia and the country's financial, commercial, educational, and media center. The city also hosts the United Nations station, located in the Kazanchis district. The population was estimated at 4.4 million in 2017.

The Addis Ababa Water Supply and Sewerage Authority (AAWSA) provides, among other services, water and wastewater (mainly human excreta) collection and disposal services. The major wastewater disposal system in Addis Ababa, as is the case in other big cities and medium towns of the country, is by use of vacuum trucks. According to the recent data of AAWSA, wastewater practices in the metropolitan area are poor (AAWSA). The estimated wastewater production in the area is $398,985 \mathrm{~m}^{3} /$ day. From the total wastewater which should be removed in the Metropolitan only $0.43 \%$ are disposed every day. It is estimated that in Addis Ababa city, only $7.2 \%$ of the liquid waste is disposed in the appropriate way and the remaining $92.8 \%$ is disposed inappropriately into rivers and rainwater channels. The Kaliti Catchment is the only one where a sewerage facility exists with a central wastewater treatment system. It is the Northwest part of the city covering an area of $210 \mathrm{~km}^{2}$, including the centre of Addis Ababa. According to the 2007 census, $14.3 \%$ of the housing units in Addis Ababa had no toilet facility and 51\% of the households use private and shared pit latrines [30].

The first design capacity of the Kaliti WWTP was about $7500 \mathrm{~m}^{3} /$ day with a biochemical oxygen demand load of $3500 \mathrm{~kg} /$ day. Currently, the inlet flow is up to $47,500 \mathrm{~m}^{3} /$ day, reaching double during the rainy season. The Kaliti wastewater collection system was designed based on average water consumption of $150 \mathrm{~L} /$ capita/day to serve an equivalent 
population of 200,000 people. The Kaliti WWTP is currently overloaded and new expansion and rehabilitation of the treatment plant is presently under construction.

The plant constructor claims that following the construction of the WWTP and during the pre-commissioning and commissioning of the plant, AAWSA provided staff training to facilitate the take-over of operations and maintenance. The Contractor trained 35 of the client's staff members, however, when the time came for the takeover only 18 of the trained staff showed up. Meetings with AAWSA management were held to stress the importance of maintaining and operating the plant and emphasize the importance of having enough staff available $24 / 7$.

Grit chamberlines and screens are used as primary treatment. The choice of circular clarifiers was mostly the preference of the designer. For organic load removal, an UASB (Upflow Anaerobic Sludge Blanket) process and trickling filters are used. UASB reactors are attractive in tropical countries because they work better at mesophilic conditions (Figure 4). No additional treatment is present to reduce the nutrient load. After the UASB treatment, effluent is conveyed to secondary sedimentation, then to facultative and maturation ponds. Plant upgrading projects aim at transforming these ponds into engineered wetlands. Free Water Surface (FWS) wetlands were preferred because they are much simpler and less costly to adapt from an existing pond. Wetlands are generally effective in removing nutrients, metals, and organics from wastewater [31,32]. In addition, pollutants coming from industry activities - which could inhibit plant growth in agricultural fields or cause health problems-will be removed. The sludge produced by the process is treated by gravity thickening, then dewatered in drying beds and lagoons. Based on these data, the Kaliti wastewater treatment plant discharges the effluents difficult to reuse for irrigation.

Treated effluent is discharged into the Akaki river. The wastewater irrigation practices in Akaki River reached the attention of researchers due to their high economic benefit and adverse effects on farmers, public health, and the environment. Since the 1940s, a variety of vegetables have been produced within and around the city, mainly using water from the Akaki River. The irrigation is carried out informally by smallholders without conventional irrigation infrastructure. They provide about $60 \%$ of the vegetables on the cities' vegetable markets, which provides their main source of household income [33] as cited by Van Rooijen (2009) [34].

The effluent quality of Kaliti WWTP is reported in Table 2, compared with the WHO existing standards for irrigation purposes. Considering the overall data, the value of $\mathrm{BOD}_{5}$ concentration reported by Abiye et al. (2009) [35] seems not representative of the plant and therefore it is not considered. These data show that wastewater in the Kaliti wastewater treatment plant does not fulfill the reference standards for irrigation. Total coliform content reported by Abiye et al. (2009) is above ten times the limit value.

Table 2. Effluent quality of Kaliti WWTP.

\begin{tabular}{ccccc}
\hline Parameter & Unit & $\begin{array}{c}\text { WHO Standard } \\
\mathbf{( 2 0 0 6 )}[36]\end{array}$ & $\begin{array}{c}\text { Gebresilassie } \\
\mathbf{( 2 0 2 0 )}[37]\end{array}$ & $\begin{array}{c}\text { Abiye et al. } \\
\mathbf{( 2 0 0 9 )}[35]\end{array}$ \\
\hline COD & $\mathrm{mg} / \mathrm{L}$ & 60 & 202 & 231 \\
BOD $_{5}$ & $\mathrm{mg} / \mathrm{L}$ & 20 & 133 & 23.3 \\
TSS & $\mathrm{mg} / \mathrm{L}$ & 30 & 66 & 560 \\
Helminthes & eggs/L & 1 & No data & No data \\
& E. coli/L & 105 & No data & 1200 \\
\hline
\end{tabular}




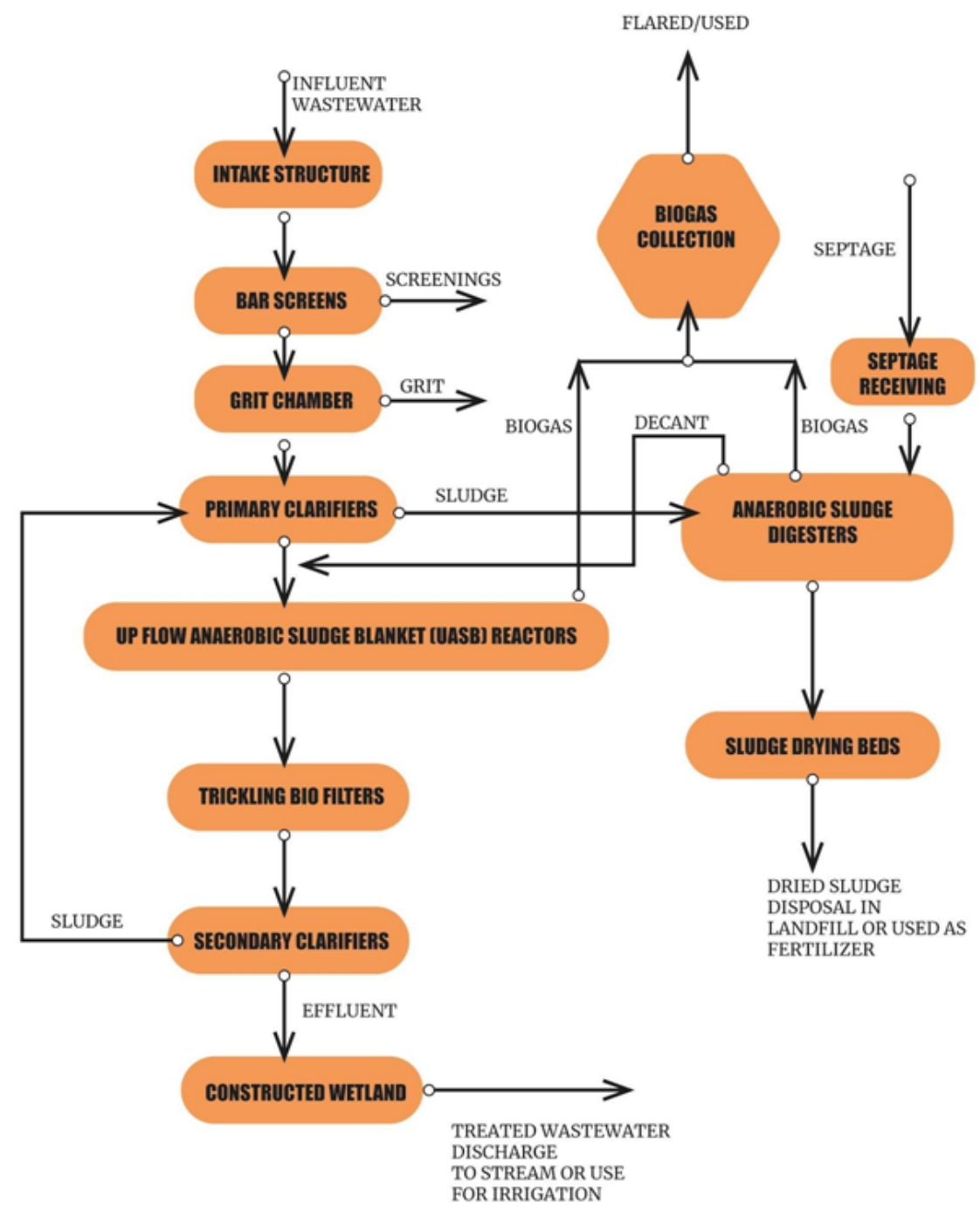

Figure 4. Kaliti WWTP process scheme.

\subsection{Kauma WWTP (Lilongwe, Malawi)}

Lilongwe is the capital city of Malawi. In 2018, the resident population was 989,318. The city area is $328 \mathrm{~km}^{2}$. The area is characterized by a sub-tropical climate. The average annual temperature and rainfall are $21^{\circ} \mathrm{C}$ and $852 \mathrm{~mm}$ respectively. The urban settlement has different zones defined by housing density (low, medium, and high-density zones) and industrial zones. Higher density housing zones correlate with medium and lower incomes and vice versa [38]. The water supply in Lilongwe is managed by the Lilongwe Water Board (LWB). Water is currently supplied to about 70\% of city residents [39]. In recent years, Lilongwe city has experienced floods during the rainy season (from November to April). This was probably also due to infrastructural development and poor drainage system within the city.

Physical and biological treatments take place at the WWTP through stabilization ponds (Figures 5 and 6). Preliminary treatments are performed with screening bars, grit tanks, and equalization tanks. Primary sedimentation takes place in rectangular tanks, where the influent is treated anaerobically. Maturation ponds are the secondary and final stages of the treatment process. Sub-tropical climate provides favorable conditions for this type of secondary treatment, due to its simplicity in construction, flexibility concerning degree of treatment, low maintenance requirements, low energy consumption, and easiness of operation. The dissolved organic matter is allowed to settle and after 21 days the effluent is conveyed to three stabilization ponds. No treatment is foreseen to reduce nutrient concentrations. Treated wastewater is finally discharged into the Lilongwe River. There are 
no associated plants for sludge treatment in the WWTP. The costs for construction, energy, and operation and maintenance of such plants are the main constraints. Sludge aerobic digestion takes place in the facultative oxidation ponds. Sludge is dewatered before it is removed to reduce water content. Sludge is dried for at least a month after draining the facultative ponds. After sedimentation has taken place in both anaerobic and facultative ponds, sludge is directed to drying ponds/beds through gravity. Here, water content from the sludge is reduced through evaporation. The dried sludge is freely removed and used in agriculture activities. People or farmers tend to use it as inorganic fertilizer or as a soil improver. Dried sludge is provided for free.

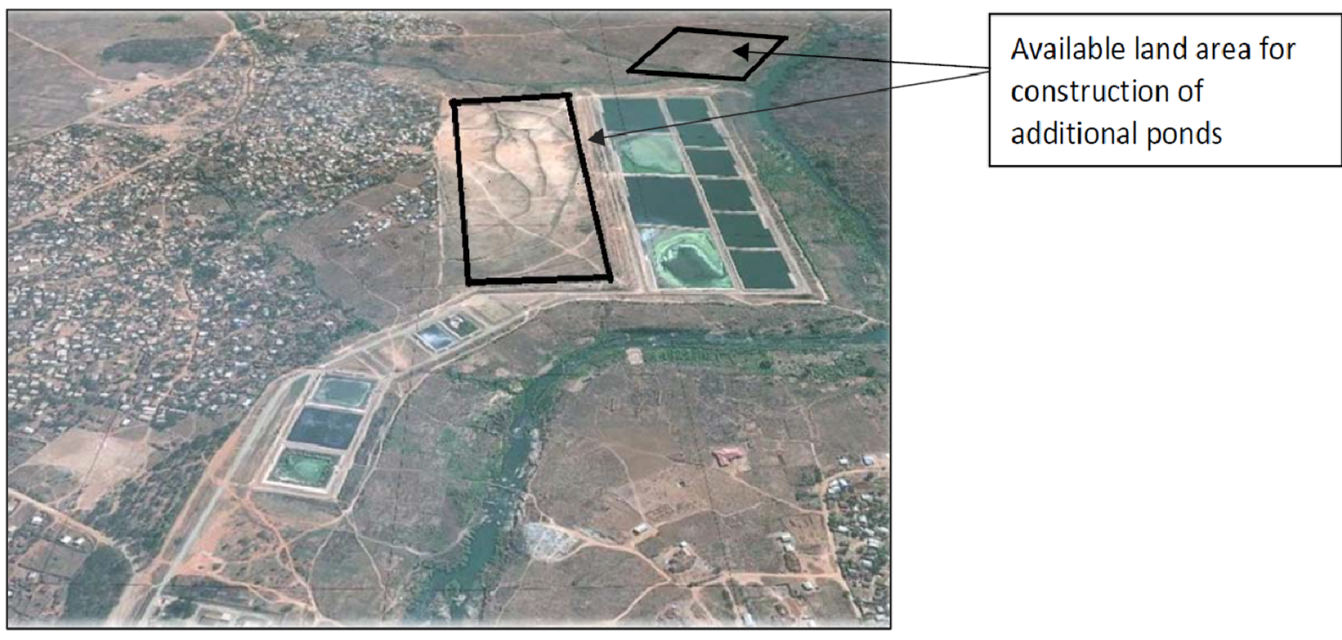

Figure 5. Existing Kauma Sewage Ponds and Expansion Area [40].

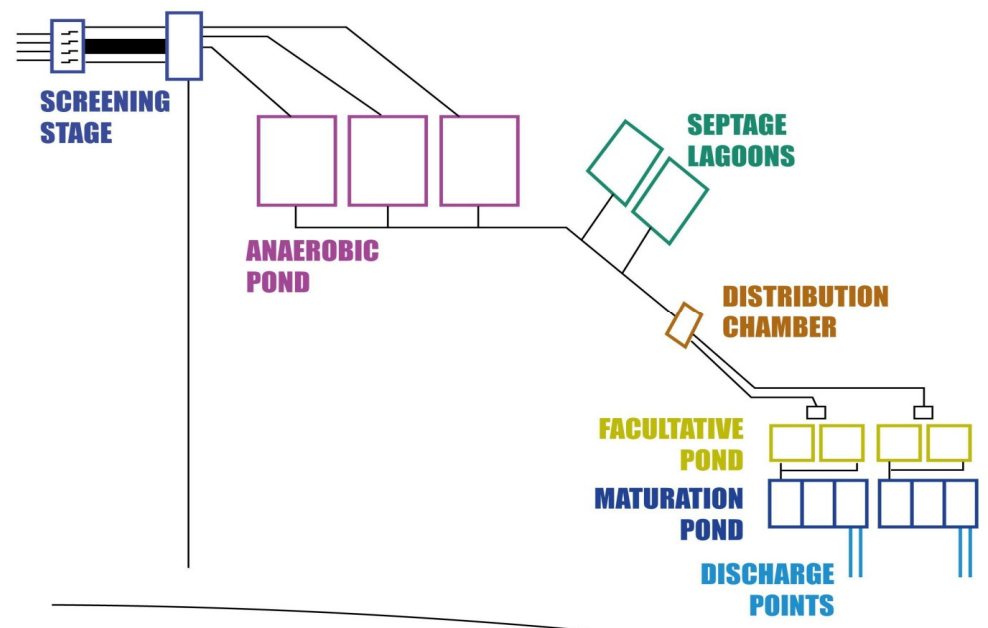

Figure 6. Sketch for Kauma Sewage Treatment plant. Not drawn to scale. Adapted from [41].

Project implementation was governed by a set of agreements. The World Bank signed a financing agreement with the Ministry of Finance, Economic Planning and Development (MoFEPD) as the recipient of the credit/grant. MoFEPD in turn signed a subsidiary financing agreement with Lilongwe Water Board (LWB) with terms and conditions acceptable to the World Bank. All project operational modalities were detailed in a Project Implementation Manual [40].

At present, donors such as the European Investment Bank support the government in operations and maintenance. The citizen pays for water bills which contribute to maintenance and operation of the treatment plant. Sewer network expansion is limited to those areas of the city that are within the vicinity of an existing trunk sewer. Priority of 
sewer expansion areas identified includes Area 3, 6, 12, 18, 30, 47, and 48 in Lilongwe City (Figure 5). However, most of the city is still not connected to the sewer line. The majority of the population uses septic tanks, while, in some areas, there is no running water and people use pit latrines. The WWTP is gravity fed by the pipe network system. Therefore, the communities that are on higher elevation are connected to the network unlike those that are on the lower elevation.

The plant construction and management provided job opportunities to various skilled and technical levels. During construction, plant operators and builders had an opportunity to get employment. The plant also generates jobs for private companies for pit emptying and transportation of wastes to the treatment plant. Currently, the plant personnel consists of six skilled and 10 unskilled units.

Concerning the quality of the effluent, recently an analysis of samples taken from the maturation ponds indicated a high level of faecal coliforms, meaning that the quality of effluent does not meet the required standards (Table 3).

Table 3. Effluent quality of Kauma WWTP.

\begin{tabular}{ccccc}
\hline Parameter & Ref. [42] & Ref. [43] & MBS & WHO \\
\hline COD & $39-97$ & $21-55.1$ & 60 & 60 \\
BOD $_{5}$ & $13-19$ & $14.2-35.8$ & 20 & 20 \\
TSS & $21-84$ & $93-118$ & 30 & 30 \\
\hline
\end{tabular}

The following issues were reported on the plant, that possibly contribute to the low reported efficiency of the plant:

- Grit chamberlines and distribution chambers were cleaned less frequently than desired;

- $\quad$ Effluent discharge pipes were not cleaned at all;

- Greasing of gate valves and movable weir spindle shafts were not done;

- Monitoring of effluent quality was not done;

- Desludging of anaerobic ponds was done once every two years;

- $\quad$ Filling of a pond maintenance record sheet was not done;

- Equipment and materials for Operation \& Maintenance works were reported not working;

- Lack of resources was reported as the main cause for not carrying out some O\&M activities.

Recently, the LWB announced a rehabilitation and upgrading project of the Kauma WWTP, that should include the following actions:

- Desludge and rehabilitate the existing ponds;

- Construction of additional facilitative and maturation ponds to increase the treatment capacity from around $6000 \mathrm{~m}^{3}$ to about $8700 \mathrm{~m}^{3}$ per day;

- Flow measurement equipment installation;

The sub-project under Priority Sanitation Improvements will finance rehabilitation and expansion of about $92 \mathrm{~km}$ of sewerage network and connecting approximately $5000 \mathrm{new}$ households to the sewer network and upgrading of the Kauma WWTP.

\section{Sustainability Aspects}

The concept of sustainability has its roots in the seminal work of the Club of Rome conducted in the early 1970s. In 1970, an international team of researchers at the Massachusetts Institute of Technology began a study of the implications of continued worldwide growth. The report resulting from their work, entitled Limits to Growth [44], issued the following message: "Man can create a society in which he can live indefinitely on earth if he imposes limits on himself and his production of material goods to achieve a state of global equilibrium with population and production in carefully selected balance". In 1987, The Brundtland Report [45] found that the critical points and global problems of the environment are essentially due to the great poverty of the south and the unsustainable production and consumption patterns of the 
north. The report highlighted the need to implement a strategy capable of integrating the needs of development and the environment. This strategy has been defined with the term "sustainable development" or "sustainability". The definition given to the concept of sustainable development was then the following: "Sustainable development is that development which allows the present generation to satisfy their own needs without compromising the ability of future generations to satisfy their own". This means satisfying different expectations or trying to meet the varied expectations and needs of all people at present and in the future society, (i) promoting personal wellbeing; (ii) social cohesion, closeness, and inclusion; and (iii) creating equal opportunities [46,47].

The information collected throughout this research project, as well as the analysis of the case studies proposed by the participants, raise an important point of discussion concerning the current sustainability of sanitation practices in African countries. Following the project structure, the evidence collected were separated into environmental, economic, social, and technical aspects. The main findings are resumed in the following.

\subsection{Environmental and Sanitary Sustainability}

The evidence collected confirms a significant lack of water sanitation in all the African countries. The analysis of case studies reveals that few centralized WWTPS are present, and, in principle, their design respected the common standards. Nevertheless, the available data show that the treatment facilities do not fully treat the wastewater to the standard, as evidenced by effluents with a high concentration of $\mathrm{BOD}_{5}$, coliform bacteria, total phosphorus, total nitrogen, and turbidity $[42,48]$. The concentration of these parameters does not comply with the country (if present) and WHO standards. In addition, operations errors in the water distributions systems were reported, for which the population was exposed to unclean water. This causes the pollution of superficial water bodies posing environmental and health threats to the entire river basin ecosystem. In addition, bad functioning causes gaseous emissions that pose a threat to human settlements surrounding the WWTPs [49].

The potential impacts and the sanitary risk are not fully taken into account [6]. In Egypt, the mismanagement of the by-products of wastewater treatment from unofficial suppliers leads to mixing sewer with water that finally lead to health issues like diarrhoea in children and hepatitis $C$ virus, which affects 35 million people in the country. In Benin, common waterborne diseases include Malaria, diarrhoea, typhoid fever and abdominal pain. In Ethiopia, up to $60 \%$ of the current disease burden is attributable to poor wastewater management and sanitation systems, whereas $15 \%$ of total death are from diarrhoea, mainly among children under five. In Malawi, the most common waterborne diseases include diarrhoea and cholera (but also typhoid and bilharzia). Treating such diseases has a great impact on the economy of the countries.

Owing to the information collected, all the considered countries have environmental impact assessment (EIA) regulations. In all the selected cases, plant construction and operation were subject to EIA. For the Kaliti WWTP, the operation of the plant had a detailed environmental and social monitoring plan that was implemented in collaboration with stakeholders of various kinds. Such integrated management plan established a Project Steering Committee (PSC) that is composed of the Addis Ababa Water and Sewerage Authority (AAWSA), The Ministry of Works and Urban Development (MoWUD), Addis Ababa Environmental Protection Agency (AAEPA), and representatives from affected Kebeles (administrative units). For the Kauma WWTP, plant construction was subject to EIA procedure as required by the Environmental Management Act of 1996. Nevertheless, the correct application of environmental standards is still lacking.

Besides wastewater, sludge management also represents a threat to the environment and public health. In the observed cases, sludge is commonly dried on large lagoons and drying beds and that may cause some form of groundwater pollution. In addition, if dried sludge contains heavy metals and aromatic hydrocarbons, these substances would not be removed by the treatment facility. Even if technically hard to be implemented, sludge 
anaerobic digestion with biogas production overcomes part of these issues. In Kaliti WWTP, $42,820 \mathrm{~kg} / \mathrm{d}$ of solid are produced from the sludge digesters, which will be dewatered, stored on-site, and used as fertilizer. An estimated amount of $2000 \mathrm{~m}^{3} / \mathrm{d}$ of methane can be produced from the proposed sludge digesters.

The operation of WWTPs should be improved so that the following measures are put in place against environmental pollution:

- Leakages of wastewater to groundwater should be avoided;

- $\quad$ Sludge drying beds should be impermeable;

- Efficient drainage system for leachate and flood protection structures must be constructed;

- $\quad$ Temporary sludge disposal sites should be impermeable and protected from flood.

Furthermore, as African urban areas are continuously evolving, there should be territorial protection for human settlements to limit population exposure, which should be enforced by local administrations.

\subsection{Economic Sustainability}

The major actors that participate in wastewater management in the context of the selected African countries are Governments (Ministries of water, irrigation, environment, and health), regional water Boards, and municipalities of cities. Central administrations issue the general urban wastewater management strategy and water resource policies that regulate the handling, collection, treatment, and effluent release. The case studies presented were both financed by the World Bank through the signing of a set of agreements with local authorities. The operation and maintenance of WWTPs are under the supervision of such national and local authorities, for example, the Holding Company of Water and Wastewater in Egypt, the AAWSA in Ethiopia, or the LWB in Malawi.

In general, plant management is not economically sustainable. The main observed failures in operation and maintenance (O\&M) may be due to financial constraints. Plants require regular maintenance activities in the ponds, pipes, and distribution structures. In Malawi, the Kauma plant has been receiving funds from the City council to sustain the operation cost, still with support from the World Bank, but the system is not selfsustainable. Other sources of funds (a small amount) may come from sewer connection fees and disposal fees which come from septic tanks and pit latrines. Furthermore, due to a lack of funds, plants are not expanded to satisfy the population growth. Nor upgrading works are possible, to achieve a higher quality at discharge. The reuse of reclaimed water or sludge cannot provide any significant economic revenues to be distributed among the community. Sludge is recovered but it does not generate economic revenues as it is provided freely to the individuals or companies as one way of getting rid of the material. The only exception, as seen for the Ethiopian case, is represented by anaerobic digestion of the sludge, where sludge is recovered for soil reconditioning and biogas is used for electricity generation. However, the revenues collected from sludge treatment do not fully cover the expenses for running the plant. Another major problem is that citizens are not willing to pay for wastewater treatment. The majority of citizens can pay for pit emptying and transportation of wastewater but may not pay for wastewater treatment. This means that the government and the donors have almost no income from sanitation taxes and fees.

\subsection{Social Sustainability}

According to the information collected, there was complete agreement among all participants that WWTPS are socially accepted as there are no aspects related to religion or habits that are possibly in conflict with the operation and aims of these plants. The project reported in the case studies received support both from the community and the different stakeholders involved. According to the data reported by the participants, all district and sub-city authorities and experts of the different sectorial offices fully supported the projects. There were no people or groups excluded due to religion, custom, or habit. In Kaliti, the construction of the plant created temporary jobs and the emergence of small business activities around the plant, which are beneficial socio-economic impacts. 


\subsection{Technical Sustainability}

Currently, the practice of wastewater management in African countries is at an infant stage. Despite the regulations, there is low enforceability. In some countries like Benin, there is neither industrial nor municipal wastewater treatment. A part of wastewaters generated by industrial, commercial, and domestic activities is collected by sewage systems without any further treatment and the other part is directly disposed of in courtyards and streets. In Egypt, Ethiopia, and Malawi, the common treatment methods are lagoons and drying beds. Especially in suburbs, most of the time the community uses decentralized sanitation systems such as pit latrines, ventilated pit latrines, and septic tanks. These facilities are mainly concerned with reducing the sediment load rather than removing most of the harmful chemicals and pathogens. These dominant treatment types mainly remove about $30 \%$ of the organic wastes and $50 \%$ of suspended solids and bacteria [41]. The quality target of the effluent is set to use the water for agricultural practices. Since secondary and tertiary treatment are not performed, nutrients such as nitrogen and phosphorous as well as pathogens like E. coli remain in the effluent. Furthermore, heavy metals and organic contaminants may remain in the wastewater or sludge [50].

Wastewater generation has increased significantly due to the increase in population and urbanization. Centralized WWTPs need to be designed to foresee their future expansion, to accommodate more flow. In most cases, there is evidence of malfunctioning of the sewer system due to e.g., sewage system breakdown, sewer lines blockages occur, improper design of some sections, and also improper use of the sewerage systems. A case study presented of a pilot WWTP in the University of Abomey-Calavi, Benin, showed that pond systems, if well managed, can reach reasonable performance levels. The pilot plant in Abomey-Calavi is made of an anaerobic pond, a facultative pond and two lines of maturation ponds. The effluent is finally conveyed to two separate fishponds for aquaculture. The effluent from the fishponds is then used on-site for crop farming. In a previous study, the following physico-chemical parameters of the plant were monitored: total suspended solids (TSS), chemical oxygen demand (COD), biological oxygen demand (BOD 5$), \mathrm{pH}$, turbidity, nitrates, nitrites, and phosphates. The removal efficiencies observed were $93 \%$ for $\mathrm{COD}, 97 \%$ for $\mathrm{BOD}_{5}$. The percentage of removal of suspended solids is approximately $98 \%$ [51].

Wastewater and sludge reuse are promising options to alleviate water shortage challenges, but their feasibility must be carefully assessed to avoid human health issues. Restrictions and guidance need to be provided for the reuse of the wastewater or sludge that has been removed from the process $[52,53]$.

\section{Discussion and Concluding Remarks}

The case studies presented, as well as the other evidence drawn by the project activity, confirm that sanitation in African countries is still lacking and/or facing enormous problems. The inappropriate disposal of municipal wastewater and the absence of adequate sanitation facilities pose a great threat to the environment and public health. If present, WWTPs are not managed properly, thus the effluent fails to reach the required quality standards. The design and performance of the respective plants were, in most cases, properly done, but utilisation is a challenge due to the following reasons:

- mismanagement of resources;

- low capacity/knowledge in plant utilisation;

- poor monitoring and supervision of these plants;

- undefined guidelines for various stakeholders who are affiliated with the plant;

- lack of awareness among the community.

To cope with SDGs, the treating capacity of WWTP should be rapidly increased. As already discussed in previous studies [54], the choice of decision-makers must rely on the integration between centralized and decentralized systems. Regarding centralized systems, the options are between simple facilities relying on facultative and maturation ponds (as the Kauma WWTP), or more technically advanced plants (as the Kaliti WWTP). These 
latter are in general recommendable in developed countries, but their utilisation must be carefully assessed in low-income countries.

Besides the selected approach, there is a general need of improving secondary and tertiary treatments, to preserve human health by possible pathogen impacts. Introducing mechanical aeration is one possible option. Additionally, sludge treatment should be improved to minimize negative impacts and possibly introduce a source of income [55]. Anaerobic digestion, mechanical dewatering, and sludge incineration are, in principle, feasible solutions. WWTP managers should implement minimum monitoring equipment, to provide appropriate testing before discharge. Concentrations of $\mathrm{BOD}_{5}, \mathrm{COD}$, TSS, and pathogens in the effluent should be periodically measured. Another upgrading could also be introduced by constructing free surface wetlands [32]. Soil or sediment organic matters which have accumulated in the wetland pond could be absorbed, degraded, and dried regularly.

Regarding the economic conditions, it must be said that the management of centralized WWTPs is not, at present, economically sustainable. This is evidenced by problems such as leakages of sewer pipes and inadequate monitoring of the plant, possibly due to financial constraints. WWTPs require regular maintenance activities in the ponds, pipes, and distribution structures. WWT sludge is recovered but it does not generate economic revenues. In addition, restrictions and guidance need to be provided for the reuse of the wastewater or sludge that has been removed from the process as these may have health impacts on the population.

This research study intended to attract the interest of sanitation experts on the necessity to start collecting data on wastewater treatment and management in African countries. As mentioned, considering water demand increase, due to population growth, urban settlements development and access to drinking water improvement, the challenges to be faced in African countries are huge and more and more urgent. Starting from data collection on sanitation issues, it provided additional knowledge of the different contexts, to focus on the main weakness and needs in terms of sanitation, hygiene, and health, evaluate the most adapted solutions from a technical, economic, environmental, and social point of view and, finally, motivate decision-makers to implement the best strategy to reverse the course.

African urban areas are expanding at a tremendous rate. With an increase of population in urban areas, there will be more demand for water and sanitation facilities. Thus, it is imperative to further increase the treatment capacity in the coming years. There is a need for human capacity to generate data on the quantity and quality of wastewater and plan for an efficient wastewater management system that can help to reduce the potential public health risks associated with wastewater management. Human capacity development is required for identifying a combination of treatment and crop restrictions, safe wastewater application methods, and control of human exposure which will help to ensure safety to the public as well as the environment.

Author Contributions: Conceptualization, M.R., M.Z. and S.G.; Methodology, M.R., M.Z. and S.G.; Validation, M.R., M.Z., S.G., A.D., O.A.H.K., M.M., L.M. and A.S.; Formal Analysis, M.R., M.Z., S.G., A.D., O.A.H.K., M.M. and L.M.; Investigation, M.R., M.Z., S.G., A.D., O.A.H.K., M.M. and L.M.; Resources, M.Z., M.R. and S.G.; Data Curation, M.R., M.Z., S.G., A.D., O.A.H.K., M.M. and L.M.; Writing-Original Draft Preparation, M.R., M.Z., S.G., A.D., O.A.H.K., M.M. and L.M.; WritingReview \& Editing, M.R., M.Z., S.G., A.D., O.A.H.K., M.M. and L.M.; Visualization, M.R. and S.G.; Supervision, M.R., M.Z. and S.G.; Project Administration, S.G. and M.Z.; Funding Acquisition, S.G. and M.Z. All authors have read and agreed to the published version of the manuscript.

Funding: This research was financed by the Ministry of Foreign Affairs and International Cooperation of Italy-Analysis, Programming Statistical and Historic Documentation Unit in the context of the call for proposals 2020 .

Institutional Review Board Statement: Not applicable.

Informed Consent Statement: Not applicable. 
Data Availability Statement: Not applicable.

Acknowledgments: The authors acknowledge all the participants of the technical e-learning course on wastewater treatment 2020 edition who have contributed to the UAP Sanitation Project.

Conflicts of Interest: The authors declare no conflict of interest.

\section{References}

1. WWAP (United Nations World Water Assessment Programme). Wastewater: The Untapped Resource. In The United Nations World Water Development Report; UNESCO publishing: Paris, France, 2017.

2. Koop, S.H.A.; van Leeuwen, C.J. The challenges of water, waste and climate change in cities. Environ. Dev. Sustain. 2017, 19, 385-418. [CrossRef]

3. Wang, H.; Wang, T.; Zhang, B.; Li, F.; Toure, B.; Omosa, I.B.; Chiramba, T.; Abdel-Monem, M.; Pradhan, M. Water and Wastewater Treatment in Africa-Current Practices and Challenges: Water and Wastewater Treatment in Africa. Clean Soil Air Water 2014, 42, 1029-1035. [CrossRef]

4. Nansubuga, I.; Banadda, N.; Verstraete, W.; Rabaey, K. A review of sustainable sanitation systems in Africa. Rev. Environ. Sci. Biotechnol. 2016, 15, 465-478. [CrossRef]

5. Abidjan; Nairobi; Arendal. AfDB, UNEP and GRID-Arenda Sanitation and Wastewater Atlas of Africa. Available online: https:/ / www.afdb.org/en/documents/sanitation-and-wastewater-atlas-africa (accessed on 15 November 2021).

6. Gwenzi, W.; Chaukura, N. Organic contaminants in African aquatic systems: Current knowledge, health risks, and future research directions. Sci. Total Environ. 2018, 619-620, 1493-1514. [CrossRef]

7. Creswell, J.W.; Creswell, J.D. Research Design: Qualitative, Quantitative and Mixed Methods Approaches, 2nd ed.; Sage: Thousand Oaks, CA, USA, 2003; ISBN 978-1-5063-8670-6.

8. Borowski, P.F. Significance and Directions of Energy Development in African Countries. Energies 2021, 14, 4479. [CrossRef]

9. Borzooei, S.; Campo, G.; Cerutti, A.; Meucci, L.; Panepinto, D.; Ravina, M.; Riggio, V.; Ruffino, B.; Scibilia, G.; Zanetti, M. Feasibility analysis for reduction of carbon footprint in a wastewater treatment plant. J. Clean. Prod. 2020, 271, 122526. [CrossRef]

10. Egypt Egyptian Code for Design and Implementation of Pipelines for Drinking Water and Sewage Networks. Available online: https:/ / www.susana.org/en/knowledge-hub/resources-and-publications/library/details/2851 (accessed on 15 November 2021).

11. Morsy, K.M.; Abdelatif, G.; Mostafa, M.K. Comprehensive Assessment for the Potential Environmental Impacts of the Grand Ethiopian Renaissance Dam on the Downstream Countries: Itaipu Dam in the Rearview Mirror. Air Soil Water Res. 2021, 14, 11786221211041964. [CrossRef]

12. Strategie Nationale D'assainissement Des Eaux Usees En Milieu Urbain. Available online: https://www.pseau.org/outils/ ouvrages/Strategie_nationale_d_assainissement_des_eaux_usees_en_milieu_urbain_au_B_nin_2007_2015.pdf (accessed on 15 November 2021).

13. Benin Ministry of Health National Health Development Plan. Available online: https://www.prb.org/wp-content/uploads/20 18/05/Plan-National-de-De\%CC\%81veloppement-Sanitaire-2009-2018.-Be\%CC\%81nin.pdf (accessed on 15 November 2021).

14. International Secretariat for Water Benin Blue Book. Available online: https://www.joinforwater.ngo/sites/default/files/livre_ bleu_benin-rapport_pays.pdf (accessed on 15 November 2021). (In French).

15. Benin Republic National Water Policy. Available online: http:/ / eaubenin.bj/docs/Strategie/Projet_Politique_Nationale_Eau_ validee_101108.pdf (accessed on 15 November 2021). (In French).

16. Benin Republic Decree 2001-109 of 4 April 2001. Fixing the Quality Standards of Residual Water in the Republic of Benin. 2001. Available online: http:/ / extwprlegs1.fao.org/docs/pdf/ben86060.pdf (accessed on 15 November 2021). (In French).

17. World Health Organization (WHO); The United Nations Children's Fund (UNICEF). Progress on Household Drinking Water, Sanitation and Hygiene 2000-2020: Five Years into the SDGs; UNICEF: New York, NY, USA, 2021.

18. Ethiopian Ministry of Water Resources, Irrigation and Electricity (MOWIE). National Guidelines for Urban Water Supply Sewerage Services; Ministry of Water, Irrigation and Electricity: Addis Ababa, Ethiopia, 2013.

19. Ethiopian Ministry of Water Resources, Irrigation and Electricity (MOWIE). Urban Wastewater Management Strategy; Ministry of Water, Irrigation and Electricity: Addis Ababa, Ethiopia, 2017.

20. Malawi National Statistical Office. Malawi Population and Housing Census. Available online: http:/ / www.nsomalawi.mw / images/stories/data_on_line/demography/census_2018/2018\%20Malawi\%20Population\%20and\%20Housing\%20Census\% 20Main\%20Report.pdf (accessed on 15 November 2021).

21. Msilimba, G.; Wanda, E. Wastewater Production, Treatment, and Use in Malawi. Available online: https://www.ais.unwater.org/ ais/pluginfile.php/231/mod_page/content/188/country_report_malawi.pdf (accessed on 15 November 2021).

22. Holm, R.H.; Chunga, B.A.; Mallory, A.; Hutchings, P.; Parker, A. A Qualitative Study of NIMBYism for Waste in Smaller Urban Areas of a Low-Income Country, Mzuzu, Malawi. Environ. Health Insights 2021, 15, 117863022098414. [CrossRef] [PubMed]

23. Collet, S.; Tilley, E.; Yesaya, M. SFD Report. Available online: https://www.susana.org/_resources/documents/default/3-3545-7 -1550665329.pdf (accessed on 15 November 2021).

24. Collet, S.; Tilley, E.; Yesaya, M. SFD Report; Centre for Water, Sanitation, Health \& Appropiate Technology Development (WASHTED): Zomba, Malawi, 2018. 
25. Malawi Republic Waterworks Act. 1995. Available online: https://www.ecolex.org/details/legislation/waterworks-act-1995-no17-of-1995-lex-faoc119423/ (accessed on 15 November 2021).

26. Malawi Republic Water Resources Act. 2013. Available online: https://www.ecolex.org/details/legislation/water-resources-act2013-no-2-of-2013-lex-faoc167598 / (accessed on 15 November 2021).

27. Malawi Ministry of Irrigation and Water Development National Sanitation Policy. 2006. Available online: https://www.ircwash. org/sites/default/ files/824-MW06-19182.pdf (accessed on 15 November 2021).

28. Malawi Government Local Government Act. 1998. Available online: https://www.resakss.org/sites/default/files/Malawi\%20 1998\%20Local\%20Government\%20Act\%2042\%20of\%201998.pdf (accessed on 15 November 2021).

29. Malawi Bureau of Standards Catalogue of Malawi Standards. 2017. Available online: http://mbsmw.org/wp-content/uploads/ 2017/10/2017-Malawi-Standards-Catalogue.pdf (accessed on 15 November 2021).

30. Ethiopia Central Statistic Authority 2007 Population and Housing Census of Ethiopia. 2012. Available online: https://www. google.com/url?sa=t\&rct=j\&q=\&esrc=s\&source=web\&cd=\&ved=2ahUKEwiUwoL0laL0AhXJy6QKHTPiB-gQFnoECAcQAQ\& url=https $\% 3 \mathrm{~A} \% 2 \mathrm{~F} \% 2 \mathrm{Funstats}$. un.org $\% 2 \mathrm{Funsd} \% 2 \mathrm{Fcensuskb20 \% 2FAttachment489.aspx \% 3FAttachmentType} \% 3 \mathrm{D} 1 \& u s g=$ AOvVaw2jkT2hlF2yxGdWjc2oxLpu (accessed on 15 November 2021).

31. Omwoma, S.; Lalah, J.O.; Kueppers, S.; Wang, Y.; Lenoir, D.; Schramm, K.-W. Technological tools for sustainable development in developing countries: The example of Africa, a review. Sustain. Chem. Pharm. 2017, 6, 67-81. [CrossRef]

32. Rahman, E.; Bin Halmi, M.I.E.; Samad, M.Y.B.A.; Uddin, K.; Mahmud, K.; Shukor, M.Y.A.; Abdullah, S.R.S.; Shamsuzzaman, S.M. Design, Operation and Optimization of Constructed Wetland for Removal of Pollutant. Int. J. Environ. Res. Public Health 2020, 17, 8339. [CrossRef]

33. Weldesilassie, A.B.; Boelee, E.; Drechsel, P.; Dabbert, S. Wastewater use in crop production in peri-urban areas of Addis Ababa: Impacts on health in farm households. Environ. Dev. Econ. 2011, 16, 25-49. [CrossRef]

34. Van Rooijen, D. Urbanization, Water Demand and Sanitation in Large Cities of the Developing World: An Introduction to Studies Carried out in Accra, Addis Ababa and Hyderabad. Available online: https://hal.archives-ouvertes.fr/hal-00593005/document (accessed on 15 November 2021).

35. Abiye, T.A.; Sulieman, H.; Ayalew, M. Use of treated wastewater for managed aquifer recharge in highly populated urban centers: A case study in Addis Ababa, Ethiopia. Environ. Earth Sci. 2009, 58, 55-59. [CrossRef]

36. World Health Organization (WHO). United Nation Environmental Programme (UNEP) Guidelines for the Safe Use of Wastewater, Excreta and Greywater; WHO: Geneva, Switzerland, 2006.

37. Gebresilassie, S.A. Investigating the Challenges and Opportunities of Centralized Domestic Wastewater Management in Kaliti Catchment, the Case of Akaki-Kaliti Sub-City, Addis Ababa; Addis Ababa University: Addis Ababa, Ethiopia, 2020.

38. UN-HABITAT Lilongwe Urban Profile. United Nations Human Settlements Programme; United Nations Human Settlements Programme: Nairobi, Kenya, 2011.

39. Jussah, O.; Orabi, M.O.M.; Sušnik, J.; Bichai, F.; Zevenbergen, C. Assessment of the potential contribution of alternative water supply systems in two contrasting locations: Lilongwe, Malawi and Sharm El-Sheikh, Egypt. J. Water Clim. Chang. 2018, 11, 130-149. [CrossRef]

40. World Bank Lilongwe Water and Sanitation Project. Project Implementation Manual. Available online: https://documents1 .worldbank.org/curated/en/772611510199652447/pdf/Project-Information-Document-Integrated-Safeguards-Data-SheetLilongwe-Water-and-Sanitation-Project-P163794-Sequence-No-00.pdf (accessed on 15 November 2021).

41. Mtethiwa, A.H.; Munyenyembe, A.; Jere, W.; Nyali, E. Efficiency of Oxidation Ponds in Wastewater Treatment. Int. J. Environ. Res. 2008, 2, 149-152.

42. Mdolo, P. Treatment Efficacy of Kauma Wastewater Treatment Works in Lilongwe, Malawi for Pollution Control and Wastewater Reuse. Available online: https://www.researchgate.net/profile/Principal-Mdolo/publication/320372419_Treatment_efficacy_ of_kauma_wastewater_treatment_works_in_Lilongwe_malawi_for_pollution_control_and_wastewater_reuse/links/59e06e0 e45851537160fe3b0/Treatment-efficacy-of-kauma-wastewater-treatment-works-in-Lilongwe-malawi-for-pollution-controland-wastewater-reuse.pdf (accessed on 15 November 2021).

43. Malawi Ministry of Agriculture. Irrigation and Water Development Water Sampling Campaign in Malawi; WQPC: Lilongwe, Malawi, 2019.

44. Meadows, D.H.; Meadows, D.L.; Randers, J.; Behrens, W.W., III. The Limits to Growth; Associates-Universe Books: New York, NY, USA, 1972.

45. United Nations. Report of the World Commission on Environment and Development-Our Common Future; United Nations: New York, NY, USA, 1987.

46. Borowski, P.F.; Patuk, I. Environmental, social and economic factors in sustainable development with food, energy and eco-space aspect security. Present Environ. Sustain. Dev. 2021, 15, 153-169. [CrossRef]

47. Magis, K. Community Resilience: An Indicator of Social Sustainability. Soc. Nat. Resour. 2010, 23, 401-416. [CrossRef]

48. Kamwamba-Mtethiwa, J.; Namara, R.; De Fraiture, C.; Mangisoni, J.; Owusu, E. Treadle pump irrigation in Malawi: Adoption, gender and benefits: Treadle pump irrigation in Malawi. Irrig. Drain. 2012, 61, 583-595. [CrossRef]

49. Qu, X.; Zhao, Y.; Yu, R.; Li, Y.; Falzone, C.; Smith, G.; Ikehata, K. Health Effects Associated with Wastewater Treatment, Reuse, and Disposal. Water Environ. Res. 2016, 88, 1823-1855. [CrossRef] 
50. K'Oreje, K.O.; Okoth, M.; Van Langenhove, H.; Demeestere, K. Occurrence and treatment of contaminants of emerging concern in the African aquatic environment: Literature review and a look ahead. J. Environ. Manag. 2020, 254, 109752. [CrossRef]

51. Aina, M.P.; Djihouessi, B.; Vissin, E.V.; Kpondjo, N.M.; Gbèdo, V.; Sohounhloué, K.C.D. Characterization of the Domestic Wastewaters and Dimensionality of a Pilot Treatment Station by Lagooning at Abomey Calavi City-Benin. ISCA J. Eng. Sci. 2012, 1, 45-50.

52. Janeiro, C.N.; Arsénio, A.M.; Brito, R.; van Lier, J. Use of (partially) treated municipal wastewater in irrigated agriculture; potentials and constraints for sub-Saharan Africa. Phys. Chem. Earth Parts A/B/C 2020, 118-119, 102906. [CrossRef]

53. Dickin, S.K.; Wallace, C.S.; Qadir, M.; Pizzacalla, K. A Review of Health Risks and Pathways for Exposure to Wastewater Use in Agriculture. Environ. Health Perspect. 2016, 124, 900-909. [CrossRef] [PubMed]

54. Massoud, M.A.; Tarhini, A.; Nasr, J.A. Decentralized approaches to wastewater treatment and management: Applicability in developing countries. J. Environ. Manag. 2009, 90, 652-659. [CrossRef]

55. Frascari, D.; Zanaroli, G.; Motaleb, M.A.; Annen, G.; Belguith, K.; Borin, S.; Choukr-Allah, R.; Gibert, C.; Jaouani, A.; Kalogerakis, $\mathrm{N}$; ; et al. Integrated technological and management solutions for wastewater treatment and efficient agricultural reuse in Egypt, Morocco, and Tunisia: Solutions for Wastewater Treatment and Reuse in North Africa. Integr. Environ. Assess. Manag. 2018, 14, 447-462. [CrossRef] [PubMed] 